recalled with much honour, and all my friends will see that $I$ have neither a foolish nor peevish conscience, whereas otherwise I shall (I know not how long) lye under (excuse me to say) an unjust slander.

I cannot end this long letter without conjuring thee, by all that is dear unto thee, that thou wilt seriously consider all that I have written unto thee, being confident that, as thou canst not mistrust my love, so at last thou wilt not much blame the judgment of him who is eternally thine,

Charles R. ${ }^{a}$

I have received, but [have] not time now to answer, thine of the 16 th of November.

\title{
LXII. $^{\mathrm{b}}$
}

Dear Heart,

New-Castle, Dec. 5th, 1646.

Thine of the 23rd of Novem. did much comfort me to find thy judgment of affairs so right in all foundations, not without some wonder that in some particulars the queen can be so mistaken; for, whereas she rightly perceives that she is likely to be made use of to my hurt, it is strange she sees not how, which to me is very vissible, there being nothing they can work by in this kind, but only the

a This letter is printed in Clarendon's State Papers, ii. 297, from the king's original draft, with the date of November 21. From a consideration of its contents, and a com. parison of them with the king's letter of November 28 , printed at p. 76, and the queen's letter of December 14, printed in the Appendix, I am inclined to conclude that the date really was November 21 , but $I$ have thought it right to print it with the date and in the order assigned to it in the MS. which is my authority.

b Printed in Clarendon's State Papers, ii. 304, from the king's draft, between which and our MS. there are considerable variations, consisting mainly of such alterations of phrase as would be likely to be made by the king when writing out his final copy to be despatched to the queen. 
Presbyterian government. In all other things they know the queen is too clear sighted; see if ever they trouble the queen concerning the militia or my friends. I warrant thee not. But if by the queen's means they could get the Presbyterian government settled, they would be confident, and with reason, piece by piece, to work all their own ends. So that it is strange to me, that she who so wisely warns me not to loose my crown by little and little, yet is still persuading me to do that which is the only way to fall into that error which she warns me to avoid. Wherefore, I plainly see, that 'tis only misinformations which cause mistakings that make us differ in opinion; for otherwise the queen could not call my three years' concession a dispensing with my conscience, when, indeed, it is but a temporary permission to continue that unlawful possession (which, for the present, I cannot help), so as to lay a ground for a perfect recovery of that, which, to abandon, were directly against my conscience, and, I am confident, destructive to monarchy.

Now, as for thy negative councells, I fully approve, and will be constant to them all, being particularly glad that the queen understands the covenant so well as to know I must not authorize it; but let me tell thee, that an act of oblivion may go near to satisfy the queen's reason. But that which makes it never to be yielded unto is, that (albeit all the promissory part of it were not against honest men's consciences, yet) the frame of it is such, as the establishing of it is a perpetual authorising of rebellion.

I have done my part concerning Davenant's proposition for the sending of some from thee to me, with fit assurances for their safety, for I was fain to interpret his letter, albeit I could not read it, as well as recommend the business, because the cypher was mistaken.

I will, according to thy conjuration, not think of an escape untill the Scots shall declare that they will not protect me, and now I see the opinion (I say not thine), that it is less ill for my affairs that I should be a prisoner in my own dominions than at liberty anywhere else, for I cannot escape if I stir not before the Scots declare against me; and, indeed, it may well be so, if ny friends, upon my restraint, 
declare immediately and freely for my restitution; of which I know the queen will have a care, and therefore will say no more.

The French ambassadour (at my desire) hath promised to write at large to the Queen Regent and cardinall, that such offices may be done upon the conclusion of the general peace as to make all the princes know, that my case is not only mine, but that it concerns all the Christian kings to advert unto, and that somewhat may be done to oblige the King of Spain not to meddle with Ireland, desiring thee to assist these motions with the Queen Regent and cardinal in my name.

I am so pressed to send my answer to London, that my last way of denial is to send it first to my friends in Scotland, which I did yesterday, to try how far I can engage them, so that I know not how to shun the sending it to London sometime the next week, if in the mean time something from thee do not hinder me, for I much desire thy opinion concerning Ireland; and yet I have so pen'd that article, that if the Irish give me cause, I may interpret it well enough for them; for I only say that $I$ will give full satisfaction as to the managing of the war, so that if $I$ find reason to make peace, there my engagement ends.

I desire thee to make this my interpretation known to the Irish, assuring them that what $I$ do is no meaning to abandon them, nor will I so long as there can be any reason to do otherways. This is all at present from him who is eternally thine,

Charles R.

Dear Heart,

\section{LXIII.}

New-Castle, December 12th and 19th, 1646.

I have not received any letters, or news from thee, this last week, of which I do not complain, for, as I have not mist one week

a Printed in Clarendon's State Papers, ii. 313, from the king's draft, which varies considerably from the letter as it stands in the MS. from which we print. 